DOI 10.22460/jpmi.v1i3.395-400

\title{
KEMAMPUAN REPRESENTASI MATEMATIS DAN KEAKTIFAN BELAJAR SISWA SMP
}

\author{
Nur Laila ${ }^{1}$, Wahyu Hidayat ${ }^{2}$, Heris Hendriana ${ }^{3}$ \\ ${ }^{1,2,3}$ IKIP Siliwangi, Jl. Terusan Jenderal Sudirman, Cimahi, Jawa Barat, Indonesia \\ ${ }^{1}$ lailatul.wulida0124@gmail.com, ${ }^{2}$ wahyu@ikipsiliwangi.ac.id, ${ }^{3}$ herishen@ikipsiliwangi.ac.id
}

Diterima: 20 April 2018; Disetujui: 28 Mei 2018

\begin{abstract}
This study aims to analyze and examine in depth about the ability of mathematical representation that influenced the active learning of junior high school students. The method in this research using correlational method with quantitative approach. The population in this study is all junior high school students in the city of Bandung with a sample of students selected class IX Junior High School in the city of Bandung amounted to 22 students. Instrument in this research is a test of Reverentasi mathematical ability as much as 6 item and student activity scale as much as 21 scale statement. The results of this study concluded that the ability of mathematical representation of junior high school students is positively influenced by learning activeness of $93 \%$, while $7 \%$ is influenced by other factors outside of student learning activity.
\end{abstract}

Keywords: Mathematical Representation, Activity Learning

\begin{abstract}
Abstrak
Penelitian ini bertujuan untuk menganalisis dan menelaah secara mendalam tentang kemampuan representasi matematis yang dipengaruhi keaktifan belajar siswa SMP. Metode dalam penelitian ini menggunakan metode korelasional dengan pendekatan kuantitatif. Populasi dalam penelitian ini adalah semua siswa SMP di kota Bandung dengan sampel dipilih siswa kelas IX Sekolah Menengah Pertama di kota Bandung berjumlah 22 siswa. Instrumen dalam penelitian ini berupa tes kemampuan Reresentasi matematis sebanyak 6 butir soal dan skala keaktifan belajar siswa sebanyak 21 skala pernyataan. Hasil penelitian ini memperoleh kesimpulan bahwa, kemampuan representasi matematis siswa SMP dipengaruhi positif oleh keaktifan belajar sebesar 93\% sedangkn 7\% dipengaruhi oleh faktor lain di luar keaktifan belajar siswa.
\end{abstract}

Kata Kunci: Representasi Matematis, Keaktifan Belajar

How to cite: Laila, N., Hidayat, W., \& Hendriana, H. (2018). Kemampuan Representasi Matematis dan Keaktifan Belajar Siswa SMP. JPMI - Jurnal Pembelajaran Matematika Inovatif, 1 (3), 395-400.

\section{PENDAHULUAN}

Kemampuan representasi matematis adalah salah satu kemampuan yang sangat penting untuk dimiliki siswa. Hal ini dikarenakan bahwa kemampuan representasi matematis dapat membantu siswa menemukan dan membuat suatu alat atau cara berpikir dalam mengkomunikasikan gagasan matematis dari yang sifatnya rumit dapat menjadi lebih sederhana, sehingga siswa dapat dengan mudah menyelesaikannya.(Handayani, 2015; Sabirin, 2014). 
Fakta di lapangan menunjukan bahwa kemampuan representasi siswa belum optimal. Hal tersebut terjadi karena Keterbatasan pengetahuan guru, kebiasaan siswa belajar di kelas dengan cara konvensional, dan siswa yang cenderung malas dalam mengidentifikasi suatu masalah (Hendriana, Hidayat, \& Ristiana, 2018; Murni, 2014; Muhammad, 2017).

Proses pembelajaran matematika pada hakekatnya untuk mengembangkan keaktifan siswa melalui berbagai interaksi dan pengalaman belajar. Aktifitas siswa menjadi hal yang penting karena kadangkala guru lebih menekankan pada aspek kognitif, dengan menekankan pada kemampuan mental yang dipelajari sehingga hanya berpusat pada pemahaman bahan pengetahuan. Keaktifan siswa dalam belajar merupakan persoalan penting dan mendasar yang harus dipahami, disadari dan dikembangkan oleh setiap guru dalam proses pembelajaran. (Ramlah, Firmansyah, \& Zubair, 2015).

Dari pemaparan fakta ini, perlu adanya pembelajaran yang mengkondisikan siswa aktif dalam belajar matematika. Untuk mengembangkan kemampuan matematis siswa, maka pembelajaran harus menjadi lingkungan dimana siswa mampu terlibat secara aktif dalam banyak kegiatan matematika yang bermanfaat. Siswa harus aktif dalam belajar, tidak hanya menyalin atau mengikuti contoh-contoh tanpa tahu maknanya (Effendi, 2012). Berdasarkan hal tersebut, perlu dilakukan penelitian yang menjadi urgensi dari permasalahan tentang seberapa besar kemampuan representasi matematis dipengaruhi oleh keaktifan belajar siswa.

\section{METODE}

Metode dalam penelitian ini menggunakan metode korelasional dengan pendekatan kuantitatif yang bertujuan untuk mengetahui secara mendalam tentang kemampuan representasi matematis yang dipengaruhi oleh keaktifan belajar siswa SMP. Populasi dalam penelitian ini adalah siswa SMP di kota Bandung dengan sampel dipilih siswa kelas IX Sekolah Menengah Pertama di suatu SMP di Bandung sejumlah 22 siswa. Instrumen yang digunakan dalam penelitian ini menggunakan tes dan nontes. Instrumen tes tersebut didasarkan pada penilaian karakteristik yang baik terhadap kemampuan representasi matematis, sedangkan instrumen nontes didasarkan pada penilaian karakteristik yang baik terhadap keaktifan belajar siswa.

Pada instrumen tes kemampuan representasi matematis terdiri dari 6 soal uraian dengan indikator (1) Menuliskan interpretasi dari suatu permasalahan yang di berikan dan menjawab soal dengan kata-kata atau teks tertulis, (2) Menggunakan representasi visual untuk menyelesaikan masalah, (3)Membuat persamaan atau model matematis dari permasalahan yang diberikan dan menyelesaikan masalah dengan melibatkan ekspresi matematis. Sedangkan intrumen non-tes menggunakan skala keaktifan belajar siswa sebanyak 21 skala pernyataan dengan indikator (1) memperhatikan penjelasan guru, (2) memahami masalah yang diberikan guru, (3) aktif bertanya dan menjawab pertanyaan, (4) bekerjasama dalam kelompok, (5) kemampuan mengemukakan pendapat, (6) memberi kesempatan berpendapat kepada teman dalam kelompok, (7) mempresentasikan hasil kerja kelompok. Data hasil penelitian diolah dan dianalisis menggunakan uji ststistika regresi. Namum sebelum dilakukan uji statistika regresi, dilakukan terlebih dahulu pengujian normalitas data dan uji linearitas.

\section{HASIL DAN PEMBAHASAN}

Berdasarkan hasil analisis data, diperoleh bahwa kedua variabel yaitu kemampuan representasi matematis dan keaktifan belajar siswa berdistribusi normal. Selanjutnya 
dilakukan uji linearitas kemampuan representasi matematis atas keaktifan belajar siswa dengan hasil pengujian disajikan pada Tabel 1 berikut.

Tabel 1. Uji Linearitas antara Keaktifan Belajar dan Kemampuan Representasi Siswa

\begin{tabular}{|c|c|c|c|c|c|c|}
\hline & & $\begin{array}{c}\text { Sum of } \\
\text { Squares }\end{array}$ & df & $\begin{array}{c}\text { Mean } \\
\text { Square }\end{array}$ & $\mathbf{F}$ & Sig. \\
\hline \multirow{5}{*}{$\begin{array}{l}\text { Kemampuan } \\
\text { Representasi } \\
\text { *Keaktifan } \\
\text { Belajar }\end{array}$} & & 207.091 & 14 & 14.792 & 51.773 & 0.000 \\
\hline & \multirow{2}{*}{$\begin{array}{ll}\text { Groups } & \text { Linearity } \\
& \text { Deviation }\end{array}$} & 194.546 & 1 & 194.546 & 680.912 & 0.000 \\
\hline & & 12.545 & 13 & 0.965 & 3.377 & 0.057 \\
\hline & Within Groups & 2.000 & 7 & 0.286 & & \\
\hline & Total & 209.091 & 21 & & & \\
\hline
\end{tabular}

Berdasarkan hasil uji linearitas antara keaktifan belajar dan kemampuan representasi matematis siswa, terlihat bahwa terdapat hubungan yang linear. Hal ini dikarenakan nilai Sig. dari Deviation from Linearity menghasilkan 0.057, (Sig.> $\alpha=5 \%$ ). Selain itu, tingkat linearitas antara keaktifan belajar dan kemampuan representasi tergolong kuat $(\mathrm{Sig} .=0,000)$

Selanjutnya dilakukan uji statistika regresi untuk melihat apakah terdapat pengaruh dari keatifan belajar terhadap kemampuan representasi matematis dengan hasil pengujian disajikan pada Tabel 2 dan Tabel 3 berikut.

Tabel 2. Uji regresi antara Keaktifan Belajar dan Kemampuan Representasi Siswa

\begin{tabular}{llccccc}
\hline Model & $\begin{array}{c}\text { Sum of } \\
\text { Squares }\end{array}$ & df & Mean Square & F & Sig. \\
\hline \multirow{2}{*}{1} & Regression & 194.546 & 1 & 194.546 & 267.514 & $0.000^{\mathrm{b}}$ \\
& Residual & 14.545 & 20 & 0.727 & & \\
& Total & 209.091 & 21 & & & \\
\hline
\end{tabular}

Berdasarkan pengujian regresi pada Tabel 2, didapat nilai Sig. sebesar 0.000 yang mengakibatkan bahwa keaktifan belajar siswa secara signifikan memberikan pengaruh yang positif terhadap kemampuan representasi matematis siswa pada taraf signifikan 5\%. Selain itu, besarnya koefisien korelasi adalah 0,965 dan nilai koefisien determinan sebesar 0,930. Hal ini dapat diartikan bahwa kemampuan representasi matematis siswa dipengaruhi oleh keaktifan belajar siswa sebesar 93\% sedangkan 7\% dipengaruhi oleh faktor lain di luar keaktifan belajar siswa.

Tabel 3. Model Summary

\begin{tabular}{ccccc}
\hline Model & R & R Square & $\begin{array}{c}\text { Adjusted R } \\
\text { Square }\end{array}$ & $\begin{array}{c}\text { Std. Error of the } \\
\text { Estimate }\end{array}$ \\
\hline 1 & $0.965^{\mathrm{a}}$ & 0.930 & 0.927 & 0.85278 \\
\hline
\end{tabular}

Dari hasil analisis data hasil penelitian terlihat bahwa terdapat pengaruh yang positif antara keaktifan belajar terhadap kemampuan representasi matematis siswa, penyebab terjadinya pengaruh positif diantaranya: (1) siswa yang memiliki keaktifan belajar tinggi cenderung 
lebih berusaha mencari berbagai informasi yang diperoleh untuk pemecahan masalah, (2) siswa yang memiliki keaktifan belajar tinggi mampu menggunakan atau menerapkan apa yang diperolehnya dalam menyelesaikan tugas atau persoalan yang di hadapinya. Selain itu, untuk siswa dengan keaktifan belajar yang rendah, siswa memiliki perasaan takut dalam belajar matematika. Siswa mengganggap matematika merupakan pelajaran yang sulit dan sangat menakutkan. Sehingga mengakibatkan keaktifan dan hasil belajar siswa tidak bisa maksimal (Widyasari, 2013).

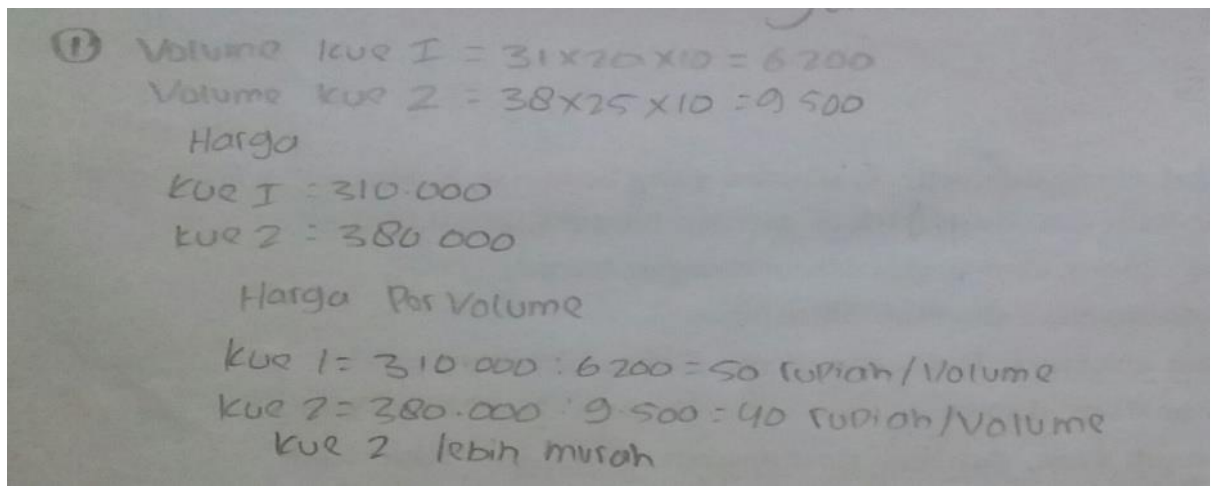

Gambar 1. Pengerjaan Soal Siswa dengan Kemampuan Representasi Matematis Tinggi

Gambar 1 adalah contoh pengerjaan soal siswa yang memiliki kemampuan representasi matematis tinggi. Siswa di atas memiliki skor yang tinggi dari skala keaktifan belajar siswa. Dari hasil jawaban siswa, siswa dapat menuliskan interpretasi dari suatu permasalahan yang diberikan dan menjawab dengan tepat. Hal ini menunjukan bahwa siswa tersebut mampu memahami masalah yang terdapat pada soal.

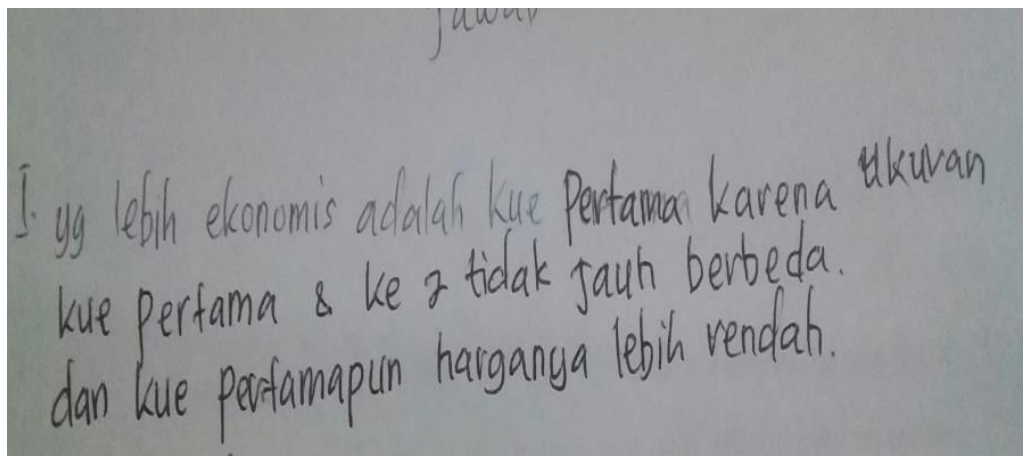

Gambar 2. Pengerjaan Soal Siswa dengan Kemampuan Representasi Matematis Rendah.

Gambar 2 adalah contoh pengerjaan soal siswa yang memiliki kemampuan representasi matematis rendah. Dari hasil jawaban siswa, siswa tidak mampu menuliskan interpretasi dari permasalahan yang diberikan serta siswa hanya menebak-nebak jawaban dengan membandingkan ukuran dan harga tanpa mengaitkan kedalam konsep volume bangun ruang sisi datar.

Keterkaitan antara kemampuan matematika dan sikap seseorang dalam menghadapi masalah dipengaruhi oleh faktor pembelajaran yang menuntut siswa menjadi aktif dalam berpikir dan berinteraksi, sehingga dapat meningkatkan kemampuan matematika yang menjadi harapan tujuan pembelajaran pada umumnya. (Hendriana, Rohaeti, \& Hidayat, 2017) 


\section{KESIMPULAN}

Berdasarkan hasil dan pembahasan yang telah disajikan, maka dapat disimpulkan bahwa kemampuan representasi matematis siswa SMP dipengaruhi positif oleh keaktifan belajar sebesar 93\% sedangkan 7\% dipengaruhi oleh faktor lain di luar keaktifan belajar siswa.

\section{DAFTAR PUSTAKA}

Effendi, L. A. (2012). Pembelajaran matematika dengan metode penemuan terbimbing untuk meningkatkan kemampuan representasi dan pemecahan masalah matematis siswa SMP. Jurnal Penelitian Pendidikan, 13(2).

Handayani, H. (2015). Pengaruh Pembelajaran Kontekstual terhadap Kemampuan Pemahaman dan Representasi Matematis Siswa Sekolah Dasar. JURNAL PGSD STKIP SUBANG, 1(1), 142-149.

Hendriana, H., Hidayat, W., \& Ristiana, M. G. (2018, January). Student teachers' mathematical questioning and courage in metaphorical thinking learning. In Journal of Physics: Conference Series (Vol. 948, No. 1, p. 012019). IOP Publishing.

Hendriana, H., Rohaeti, E. E., \& Hidayat, W. (2017). Metaphorical Thinking Learning and Junior High School Teachers' Mathematical Questioning Ability. Journal on Mathematics Education, 8(1), 55-64.

Muhamad, N. (2017). Pengaruh Metode Discovery Learning untuk Meningkatkan Representasi Matematis dan Percaya Diri Siswa. Jurnal Pendidikan UNIGA, 10(1), 922.

Murni, A. (2014). Peningkatan Kemampuan Representasi matematis Siswa SMP Melalui Pembelajaran Metakognitif dan Pembelajaran Metakognitif Berbasis Soft Skill. Jurnal Pendidikan, 4(2), 96-107.

Ramlah, R., Firmansyah, D., \& Zubair, H. (2015). Pengaruh Gaya Belajar dan Keaktifan Siswa Terhadap Prestasi Belajar Matematika (Survey Pada SMP Negeri di Kecamatan Klari Kabupaten Karawang). Majalah Ilmiah SOLUSI, 1(03).

Sabirin, M. (2014). Representasi dalam Pembelajaran Matematika. Jurnal Pendidikan Matematika, 1(2), 33-44.

Widyasari, D. (2013). Peningkatan Keaktifan Dan Hasil Belajar Matematika Melalui Pembelajaran Problem Based Learning Bagi Siswa Kelas Vii B SMP Negeri 3 Sawit Boyolali Tahun Pelajaran 2012/2013 (Doctoral dissertation, Universitas Muhammadiyah Surakarta). 
400 Laila, Hidayat, \& Hendriana, Kemampuan Representasi Matematis dan Keaktifan ... 